\title{
電界放出微小電子源型高感度光センサの広ダイナミック レンジ化
}

\author{
Photosensitive Field Emitters with Wide Dynamic Range
}

正会員澤田和 明 $^{\dagger}$, 石田誠 ${ }^{\dagger}$, 正会員 安藤隆男 ${ }^{\dagger \dagger}$

Kazuaki Sawada $^{\dagger}$, Makoto Ishida ${ }^{\dagger}$ and Takao Ando ${ }^{\dagger \dagger}$

\begin{abstract}
A new photosensitive field emitter called a "photosensitive floating field emitter" is proposed. It was constructed using an n-type Si field emitter tip and an a-Si:H p-i-n photodiode film. A back incidence type photosensitive floating field emitter was fabricated by depositing intrinsic a-Si:H and p-type a-SiC:H film on the back of a non-gated ntype cone-shaped Si emitter array. The emission current was measured as a functionof the illumination intensity and found to increase linearly. The quantum efficiency was about 0.7 . However, the emission current tendened to saturate at high illumination level.

To expand the dynamic range of the photodetector, we also examined a photosensitive field emitter composed of a gated field emitter and p-type a-SiC:H/intrinsic a-Si:H photodiode film. Its dynamic range was about 200 times wider than that of non-gated type photosensitive field emitters.
\end{abstract}

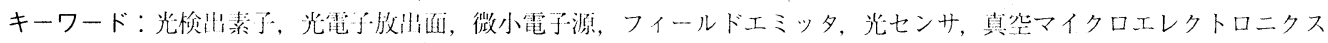

\section{1. まえがき}

光を吸収すると電子を放出する光電子放出面は様々な分 野で用いられており, 特に2 次電子増倍管やイメージイン テンシファイアでは欠かすことができない. しかしながら代 表的な可視光に感度を持つ光電子放出面 S20(Sb-Na-K-Cs) においても，その量子効率は最大でも $30 \%$ 以下と非常に 小さい.したがって，イメージインテンシファイアを用い てその信号を 10 万倍以上に増幅できても，先に述べたよ うに1次量子效率が低いため, 得られる画像の $\mathrm{S} / \mathrm{N}$ 比が悪 く，画質の悪いものであった。

近年, 半導体の微細加工技術を用いミクロンサイズの 電子源（エミッタ）を製作し，まったく新しい電子デバイ スを形成する技術，真空マイクロエレクトロニクスへの 関心が高まっている。 そのなかでも, 特に電界放出型微 小エミッタがもっとも多く研究されている1).これは, 固

1997年 6 月 10 日,映像情報メディア学会情韩センシング研究会で発表 1998 年 8 月 4 日受付，1998年10月 20 日再受付，1998年 11 月 9 日採録 †啙憍技術科学大学: 電気・電子工学系

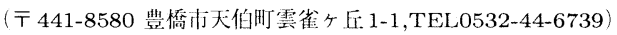
†十静阔大学電子:工学研究所

( ( 432-8011 浜松市城北 3-5-1,TEL 053-478-1301)

† Department of Electrical and Electronic Engineering, Toyohashi University of Technology

(1-1, Hibarigaoka, Tempaku-cho, Toyohashi 441-8580, Japan)

†† Research Institute of Electronics, Shizuoka University (3-5-1, Johoku, Hamamatsu 432, Japan)
体表面に $10^{7} \mathrm{~V} / \mathrm{cm}$ 以上の強電界を印加すると真空障壁が 下がり, 量子力学的トンネル効果により固体内の電子が 真空中に放出される。この機構によるエミッション電流は Fowler-Nordheimの式で与えられる2). 電界放出を起こす のに必要な強電界を固体表面に印加するためには，エミッ 夕先端を先鋭化し，先端に電界を集中させる方法が一般的 である゙่.

これまで私たちは，p 型シリコンにより製作したエミッ 夕の放出電流が $\mathrm{n}$ 型のそれと違い飽和することを報告し だ、その過程において微小エミッタの中にpn接合を設け ることで特異なエミッション特性を示すことが予想され， この現象を光電子放出デバイスとして応用することが可能 であることを考えついた。そこでn型シリコンエミッタの 裏面にアモルファスシリコン pin フォトダイオードを堆積 した可視光に感じる光電子放出面の製作を行った5). その 結果，入射する可視光に対してそれに比例した電子がその 素子より放出されることが確認できた。その量子効率は, 波長 $680 \mathrm{~nm}$ の可視光に対して約 $70 \%$ であり, 従来の光電 面のそれより, 約 2 倍の大きなものが得られた.ささらてォ トダイオードをアバランシェ増倍領域で動作させることで, 入射したフォトンの数の 3 倍の電子が放出することを確か めた5).

以上のように, 従来の光電子放出面に比べて感度が高い 光検出素子を実現することができた。しかしながら，製作 


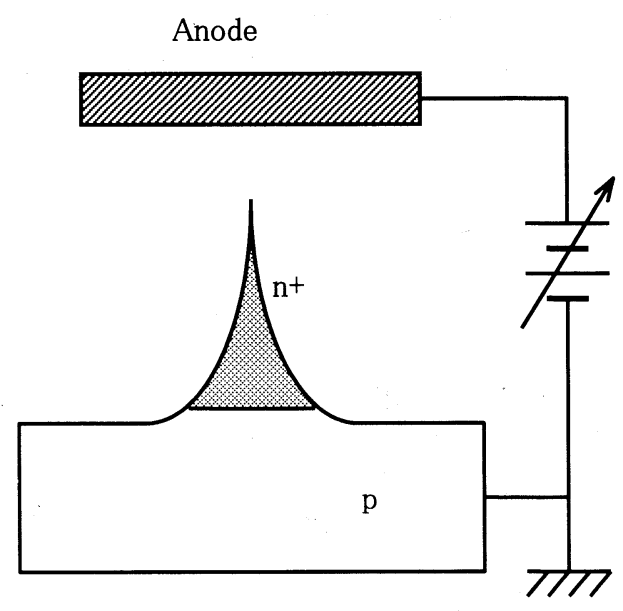

図 1 電界放出微小電子源型光センサの原理図 Schematic cross-sectional view of a proposed photosensitive floating field emitter.

した光検出素子で検出可能な光の最大光量は約 $20 \mu \mathrm{W} / \mathrm{cm}^{2}$ と低いものであった，今回は，その最大検出光量を高くす るために，電界放出部にゲート電極を持つ 3 極管構造の電 界放出微小電子源を用い, その限界を 200 倍程度増加させ ることができたので報告を行う。

\section{2. 電界放出微小電子源型光センサの動作原理}

電界放出型微小エミッタからのエミッション電流が入射 光量に依存することは，1972年にR.N.Thomasらにより 報告されている6)。このとき用いられたエミッタ材料は, p 型シリコンである。 $\mathrm{p}$ 型エミッタの場合，光を入射しなく ても表面準位を介し発生した電子によりエミッションが起 こるため，室温では，暗電流が，非常に大きい。したがっ て光検出を行うには，素子を液体窒素温度程度まで冷却し なければならない。

これを解決するために，我々は，図1に示すようにエミッ 夕内にpn 接合を内蔵させ，その先端を電気的にフローティ ングすることにより，室温でも，光検出ができるエミッ夕 構造を考えた，この構造では，先端が電気的にフローティ ングされることより，このエミッタをフローティングエミッ 夕と呼九でいる，現在のとごろ，集積回路技術を用いた工 ミッ夕作製技術では，ナノスケールであるエミッ夕先端の ばらつきを押さえることは難しい，しかしながら，今回提 案している光検出素子の放出電流は入射する光の量でコン トロールされているため，エミッ夕先端のばらつきの影響 は受けない。

図 2 と図3 は，それぞれ，暗時のフローティングエミッ 夕の概略図と暗時のエネルギーバンド図である。図中の黒 丸は電子を表す。フローティングエミッタに光が照射され ていない状態（暗時）で，アノードに大きな電圧を印加す ると，図3(a)のように, n 領域内に存在する電子が曲げら れた真空レベルをトンネルし放出される。その結果， $\mathrm{n}$ 領 域の電位が上昇し，それにより，エミッタ・アノード間の
電圧が減少するので，エミッション電流は減少する。そし て, 最終的に, 放出電流と pn 接合内部で熱的に発生する電 流とが等しくなって，図3(b)のような平衡状態に達する. このときの暗電流は, Thomasらにより報告されているも のとは違い, pn 接合領域にできる空乏層内での熱的な発生 であるために非常に低いものである。

図 4 と図5は，それぞれ，光照射時のフローティングエ ミッタの概略図とそのバンド図である．四中の黒丸，白丸 は，それぞれ，電子と正孔を表す。平衡状態に達したフロー ティングエミッタに光を照射すると，図5(a)のように空乏 層内で電子正孔対が発生し，電子は $\mathrm{n}$ 領域に，正孔は基板 側に流れる。 その結果, $\mathrm{n}$ 領域の電位は下がり，平衡状態 が崩れる，そして，再び，図5(b)のように真空レベルが深 く曲げられ，より多く電子がトンネルするようになる。こ の光の照射をやめると，フローティングエミッ夕は電子を 放出し, 平衡状態に戻る. $\mathrm{n}$ 領域の電位の下がる量は, 光

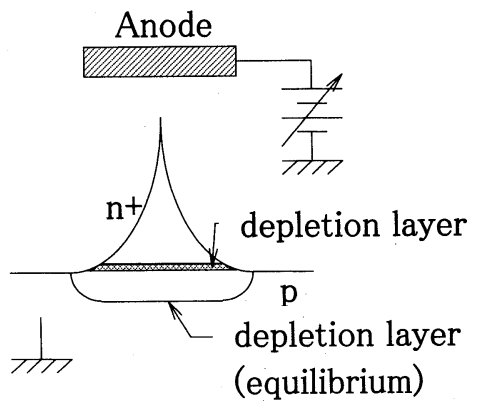

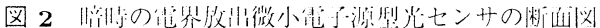
Schematic cross-sectional view of a proposed photosensitive floating field emitter at a dark condition.

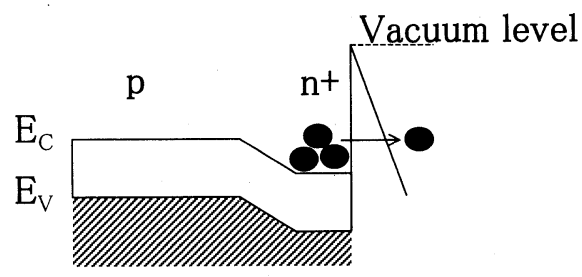

(a)

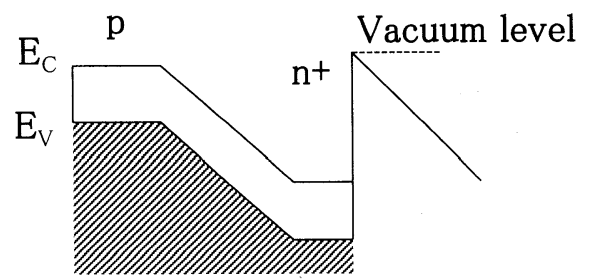

(b)

図 3 暗封の電界放出微小電子源型光センサのバンド図 A band diagram of a proposed photosensitive floating field emitter at a dark condition. 


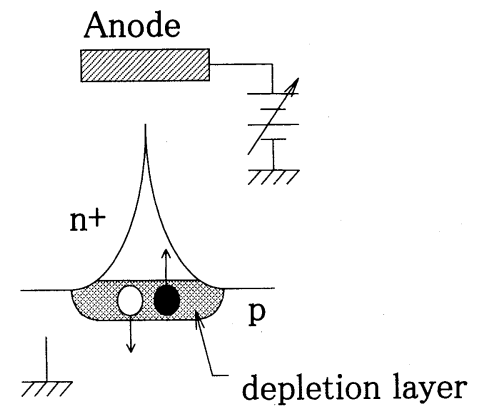

図 4 光照射時の電界放出微小電子源型光センサの断面図 Schematic cross-sectional view of a proposed photosensitive floating field emitter at an irradiation condition.

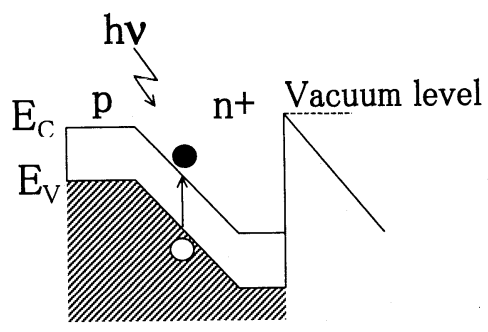

(a)

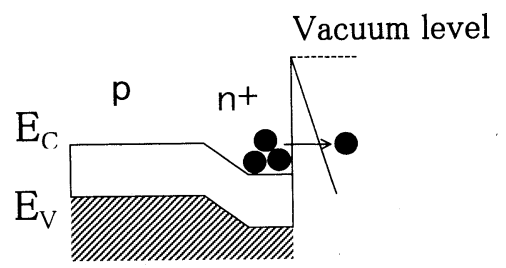

(b)

図 5 光照射時の電界放出微小笔子源型光センサのバンド戍 A band diagram of a proposed photosensitive floating field emitter at an irradiation condition.

量により変化するので，光量によりエミッタ・アノード間 の電圧が変化し，エミッション電流が変化する.

3. ゲートなし電界放出微小電子源型光検出素子の 特性

\section{1 電界放出微小電子源型光検出素子の製作}

微小電子源は $\mathrm{n}$ 型 $\mathrm{Si}(100)$ 基板上にコーン型で製作した。 この製作工程は，まずドライ酸化により，Si 基板上に約 $400 \mathrm{~nm}$ の $\mathrm{SiO}_{2}$ 膜を成長させ, 次に, $\mathrm{SiO}_{2}$ 膜上に電子ビー 么露光用レジストをスピンコートし，電子ビーム描画装置 を用いて直径 $4 \mu \mathrm{m}$ の円を描画する。このレジストをマスク にし， $\mathrm{SiO}_{2}$ 膜をエッチングする。この $\mathrm{SiO}_{2}$ 膜をマスクと して, $\mathrm{CF}_{4}$ と $\mathrm{O}_{2}$ の混合ガスによるプラズマエッチャによ り $\mathrm{Si}$ 基板をエッチングする:このとき $\mathrm{SiO}_{2}$ マスクの下に アンダーカットが生じ先端が平坦なエミッタの原型ができ
る、先端を先鋭化するために，酸化を行う。そして， $\mathrm{SiO}_{2}$ を除去してエミッタが完成する。

$\mathrm{n}$ 型シリコン基板上にコーン型エミッタを製作したのち, エミッタの裏面にプラズマC V Dにより a-Si:H pinフォト ダイオードを堆積した。エミッタがn型シリコンで製作さ れているので，実際は，ハンドープ層（i 層）を $1 \mu \mathrm{m}$ ， $\mathrm{p}$ 型 $\mathrm{a}-\mathrm{SiC}: \mathrm{H}$ 膜を $0.3 \mu \mathrm{m}$ 堆積した。次に電極として金を スパッ夕により $20 \mathrm{~nm}$ 堆積した。金電極は $1.5 \mathrm{~mm}$ 角にパ ターニングされている，試作した素子の断面構造を図 6 に 示す.

\section{2 ゲートなし電界放出微小電子源型光検出素子の 特性}

図7にゲートなし電界放出微小電子源型光検出素子の特 性を示す，アノード電圧を $450 \mathrm{~V} に$ 保ち，入射光量を変え てエミッション電流を測定した結果である．図の中の直線 は，それぞれ量子効率 1 と 0.5 の理論值を示している. 図 より入射光量の増加に伴いエミッション電流が直線的に増 加していき，さらに光量の大きな領域では，エミッション 電流が飽和していることがわかる。 入射光量とエミッショ ン電流量が比例する最大光量は約 $20 \mu \mathrm{W} / \mathrm{cm}^{2}$ と低いこと がわかる。この結果，このデバイスにおける光検出ができ るダイナミックレンジが狭くなってしまう。

4. 電界放出型光検出素子の広ダイナミックレンジ化

\section{1 光検出素子の飽和特性の原因と解決策}

この飽和の原因を明らかにするために，眓8に光電変換 を行うフォトダイオード膜の静特性と電界放出微小電子源 の放出電流特性の関係を示した。この図の電界放出型微小 電子源の放出電流特性はアモルファスシリコンpinフォト ダイオード膜を堆積する以前に，あらかじめ測定を行った ものを使用している。図8に示した特性はアノードに $450 \mathrm{~V}$

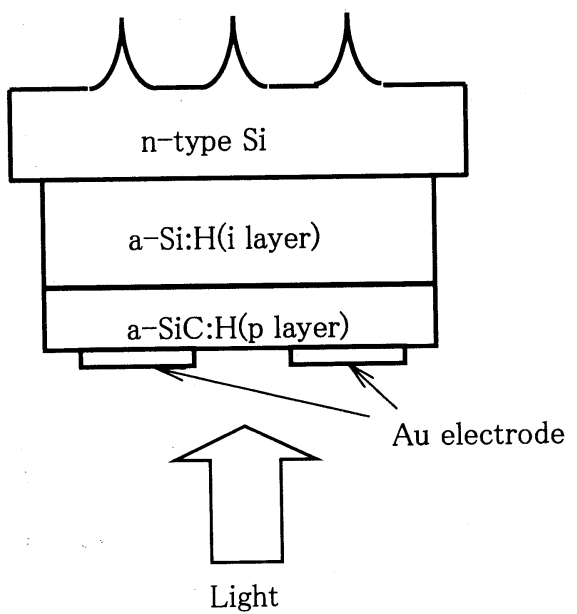

図 6 製作を行った背面入射電界放出微小笔子源型光センサの 断面図

Schematic cross-sectional view of a fabricated back irradiation type photosensitive floating field emitter. 
を印加した時を示している．提案を行っている高感度光検 出素子は, フォトダイオード膜の静特性とエミッション電 流特性が重なる動作点で動作しているものと考えること ができる. pin フォトダイオード膜を形成する以前の放出 電流特性よりアノード電極に $350 \mathrm{~V}$ 印加するとエミッショ ン電流が流れ始める。アノードに $450 \mathrm{~V}$ を印加した時は工 ミッタのポテンシャルは， $(450 \mathrm{~V}-350 \mathrm{~V})=100 \mathrm{~V} か ゙$ 最大

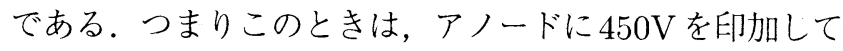
いてもエミッタのポテンシャルが100Vであるために，エ ミッタ・アノード間には $350 \mathrm{~V}$ しか印加されていない。こ れはフォトダイオードに光が照射されていないときに相当 する．実際には暗電流分だけエミッタのポテンシャルは下 がっている（ダーク電流の特性とエミッション電流 (点線) の交点). 光が照射されると光電流がエミッ夕に流れこむ ためにエミッタのポテンシャルは下がっていく（したがっ てエミッタ・アノード間の電圧は大きくなりエミッション 電流は増加する). 図8より, 光量の少ない領域では, 動 作点がフォトダイオードの光電流の飽和領域に位置してい るが, 光量を増加させていくと動作点が光電流の非飽和領

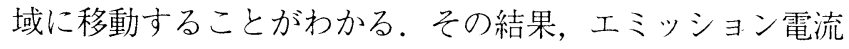
は光量を増加させても増加しなくなる。

この飽和現象を解決し，最大検出光量を大きくするには 図 9 に示すような2 通りの解決方法があると考えられる. 第1の方法として，アノード電圧を上げ，電界放出素子の 特性を，図の右方向にシフトさせることである。しかしな がらこの方法では, 光の最大検出限界は増加するが, 光が 照射されていないときに放出される暗電流成分が増えてし まう. 第 2 の方法として, 電界放出微小電子源の相互コン ダクタンスを大きくして，少量の電圧変化で，放出電流が 大きく変化する素子を電子放出部として用いることが考え られる，図に示すように，この方法は，暗電流も低く押コ えられ，第 1 の方法より最大検出光量も高くできることか ら, 有利な方法と考えられる. 微小電子源の相互コンダク タンスを高くするためには，ゲート電極付きの 3 極管構造

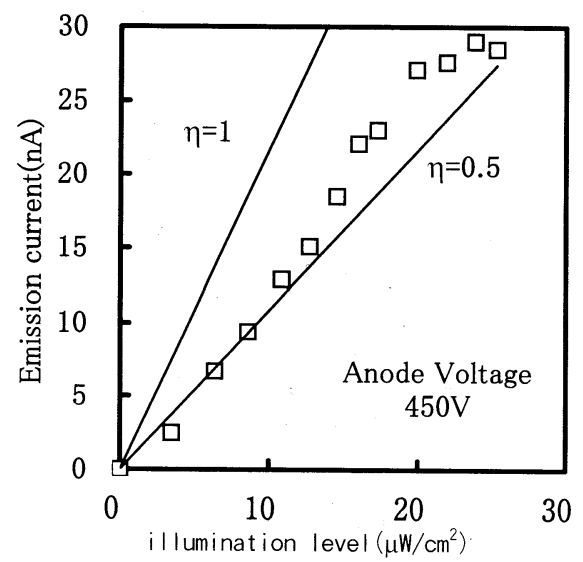

図 7 憋作老行った光センサからの放出電流の人射光依隹性 The dependence of the emission current on the incident light intensity of the non-gated photosensitive device fabricated with a-Si:H p-i-n photodiode film.

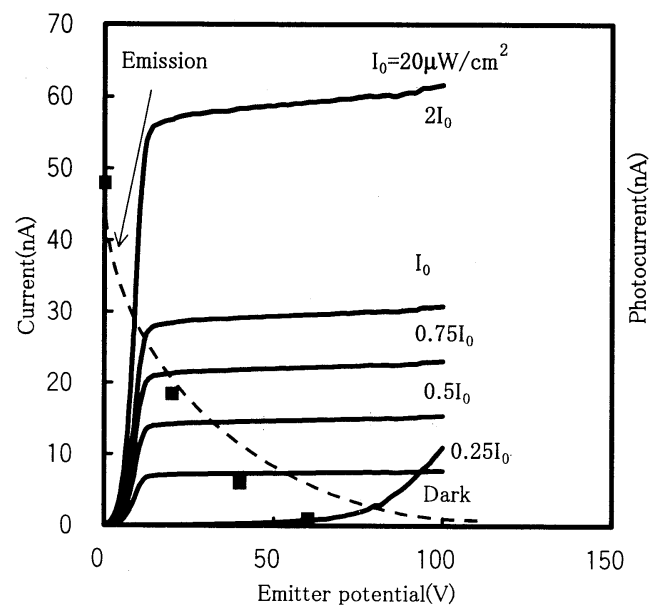

図 8 製作を行った光センサからの放出電流の人射光依存性 The load line characteristic of the n-type silicon emitter superimposed upon the a-Si:H pin photodiode film characteristic.

にすればよいと考えられる，その理由の Fowler-Nordheim の式を用いて示す。

$$
\begin{aligned}
& J=\frac{A F^{2}}{\phi} \exp \left(-B \frac{\phi^{3 / 2}}{F}\right) \\
& A, B=\text { constant } \\
& F=\beta V a \\
& \beta=\frac{2}{r \cdot \ln \left(\frac{2 d}{r}\right)}
\end{aligned}
$$

$r$ はエミッタ先端の曲率, $d$ はエミッタ先端と引き出し 電極の距離である。微小電子源の高い相互コンダクタンス とは，小さな引き出し電压の変化で放出電流 $J$ が大きく変 わることである。(3)式を見るとわかるが $V a$ のエミッタ先端の電界に及ぼす影響が大きくなり, 高 い相互コンダクタンスが得られる。エミッタ先端の曲率が 同じであれば， $\beta$ をきくするには引き出し電極と土ミッ 夕先端の距離を縮めればいいことがわかる。ゲートを持た ない2 極管構造の電界放出微小電子源の先端とアノード電 極の距離は大きくなため $\beta$ は小さくなる．ゲート付き 3 極管構造を採用することによりエミッ夕先端の電界を，工 ミッタ先端に隣接するゲートによりコントロールすること ができるために $\beta$ を大きくすることができる。したがって 高い相互コンダクタンスが得られる。

\subsection{3 極管構造をもつ電界放出型光検出素子の製作}

電子放出部のコンダクタンスを大きくするために，ゲー 卜電極を持つ電界放出電子源の試作を行った。図10に3 極管エミッタの製作プロセスを示す．まず，シリコン基板 上に約 $400 \mathrm{~nm}$ の酸化膜を成長させ，次に，酸化膜を電子 ビーム描画装置を用いて直径 $4 \mathrm{~mm}$ の円をパターニングす る (a).この酸化膜をマスクにして, $r m C F_{4}$ と $\mathrm{O}_{2}$ の混合ガ スによるプラズマエッチングによりシリコン基板をエッチ ングする(b).このとき，図のようにマスク下にアンダー カットが生じ先端が平坦なエミッ夕の原型ができる，先端 
をさらに先鋭化するためとゲートの絶縁のためにドライ酸 化を行う．次に，ゲート電極としてPoly-Si を常压CVDに より堆積させる (c).この堆積したPoly-Si を電極の形状に パターニングしたのちに，エミッ夕先端を露出させるため にフォトレジストをスピンコートする(d).これを $\mathrm{rmO}_{2}$ プラズマ (RIE) 中にさらすと，図のように，レジストの 薄いマスク上部のレジストが先に除去される。このように なったら, RIEでマスク上部の Poly-Si をエッチングする. 次に, Buff-HFでマスクのみをエッチングする。そして, RIEで，余分なPoly-Si をエッチングする (e). 最後に，エ ミッタ先端を出すために, Buff-HFでエッチングし，レジ ストを除去して完成する(f). その後，このエミッタの裏 面にプラズマCVDにより a-Si:H pin フォトダイオードを 堆積した。エミッタがn型シリコンで製作されているので, 実際は，ノンドープ層（i 層）を $1 \mu \mathrm{m}, \mathrm{p}$ 型 $\mathrm{a}-\mathrm{SiC}: \mathrm{H}$ 膜を $0.3 \mu \mathrm{m}$ 堆積した $(\mathrm{g})$. 次に電極として金をスパッ夕により $20 \mathrm{~nm}$ 堆積した．金電極は $1.5 \mathrm{~mm}$ 角にパターニングされ ている．完成した代表的なゲート構造をもつ電界放出型光 検出素子のSEM写真を図11に示寸。この写真よりエミッ 夕の先端の曲率半径は約 $50 \mathrm{~nm}$ であることがわかる。さう にゲート・エミッ夕間の距離は約 $500 \mathrm{~nm}$ であった。

4.3 ゲート構造をもつ電界放出型光検出素子の特性

まず最初にアモルファスシリコンフォトダイオード膜を 堆積する前に（製作プロセス図の (f) に対応）たゲート電 極を持つ電界放出微小電子源ゲート構造をもつ電界放出型 光検出素子の特性を調べた。

測定は $9 \times 10^{-9}$ Torr の真空度で行った。アノードとエ ミッタ間の距離は約 $3 \mathrm{~mm}$ に保った。測定に使用した微小 電子源の個数は 100 個である. 図 12 に，ゲート構造をもつ 電界放出型微小電子源のみの放出電流のゲ一ト電圧依存性 を示す。電流は約 $35 \mathrm{~V}$ から観察され始め, ゲート電压 $60 \mathrm{~V}$ で約 $3.5 \mu \mathrm{A}$ の電流值が観測できた. 2 極管構造のもので は50nA の電流を得るのに約 $100 \mathrm{~V}$ の電圧変化が必要であっ

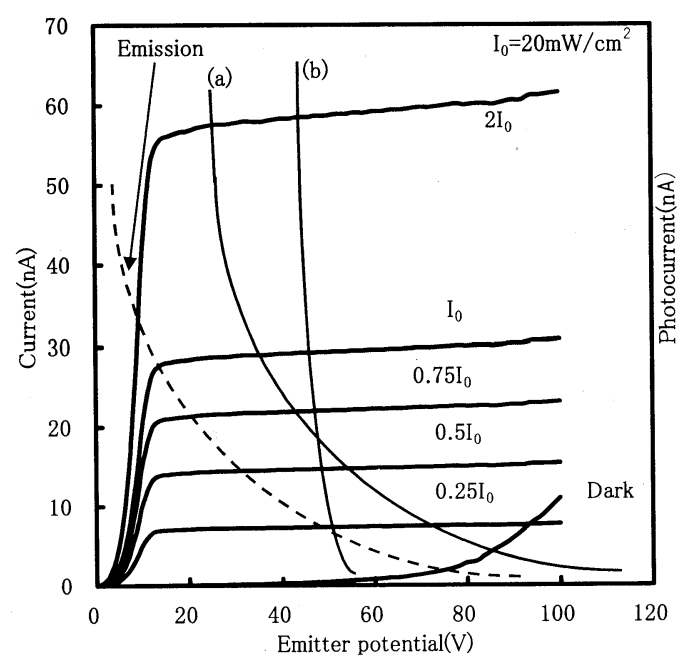

図 9 ダイナミックレンジを立くするための解決策 Solutions to expand the dinamic rage of the photosensitive field emitter.

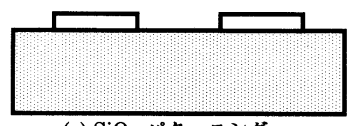

(a) $\mathrm{SiO}_{2}$ パターニンク

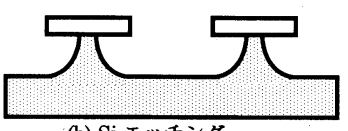

(b) $\mathrm{Si}$ エッチング

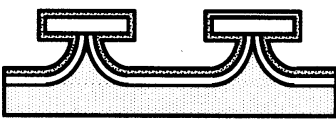

(c) Poly-Si 堆皘

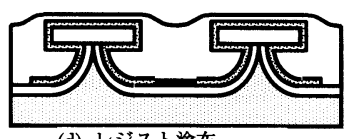

(d) レジスト盜布 (e) Poly-Si エッチング

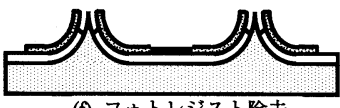

(f) フォトレジスト除去

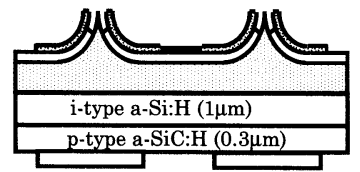

（g）フォトダイオード堆積

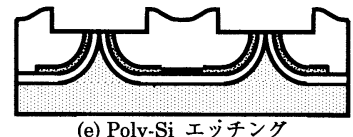

図 103 極管構造をもつ電界放出型光検出素子の製作プロセス A fablication process of the gated floating field emitter.

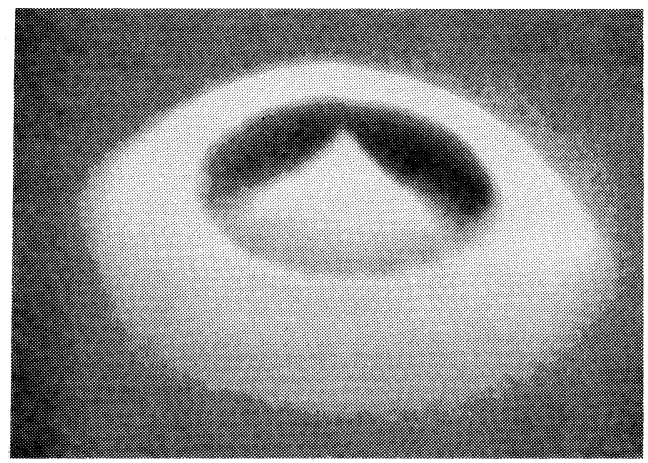

$1 \mu \mathrm{m}$

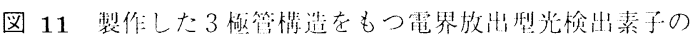
SEM $\%$ il!

A SEM photograph of the fablicated device.

たが，3極管構造を採用することで $25 \mathrm{~V}$ の電圧で約 $3.5 \mu \mathrm{A}$ の電流が得られたことになる。このように期待通り，微小 電子源の相互コンダクタンスを高くすることができた。

この放出電流の Fowler-Nordheim(F-N) プロットを 図 13 に示したＦ-N プロットは直線になっており，放出電流 が典型的な電界放出であることが確認できる。

ゲート電圧を一定に保ち，アノード電圧に対する，工 ミッタ電流，ゲート電流，アノード電流の依存性を調べた。 その結果, アノード電圧がゲート電圧より低い領域では, エミッ夕電流とゲート電流がほとんど同じであり，エミッ 夕から放出された電子はアノードには届かず，ゲート電極 に流れていることがわかった。アノード電圧を，約 $50 \mathrm{~V}$ 以 上にするとエミッタ電流とアノード電流が一致するように なり，エミッ夕から放出された電子のほとんどがアノード 電極に達するようになる。

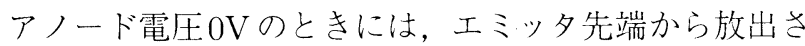
れた電子がアノード方向の電界がないため, ゲート方向の 電界に引っ張られゲートに電子が流れ込む。そしてアノー 
ド電圧を増加させていくと，アノード方向の電界が増加し てくるため，アノードに流入する電子が増加する，アノー ド電圧を充分に大きくすると，ほぼすべての放出電子がア ノードに集まる。この状態の分配率はほほ $100 \%$ ある。 アノード電流が一定值で飽和するということは，放出電子 数がゲート電圧により決まると考えられ，アノードによ る電界の影響がエミッ夕先端にほとんど及んでいないとい える。

以上のように大きな相互コンダクタンスをもつフィール ドエミッタが製作できたので，これを光検出素子の電子放 出部として使用することにした。そこでこれまで示した特 性をもつ微小電子源の裏側にアモルファスシリコン pin構 造をもつフォトダイオードを堆積させた。光吸収層である $\mathrm{i}$ 層の膜厚を $1 \mu \mathrm{m}$ とし, 電子のブロッキング層と光の空 層を兼ねた p-type のアモルファスシリコンカーバイト 層を $0.3 \mu \mathrm{m}$ 堆積させた。このフォトダイオードの特性をあ らかじめ用意されている TEG (Test Element Group) 用

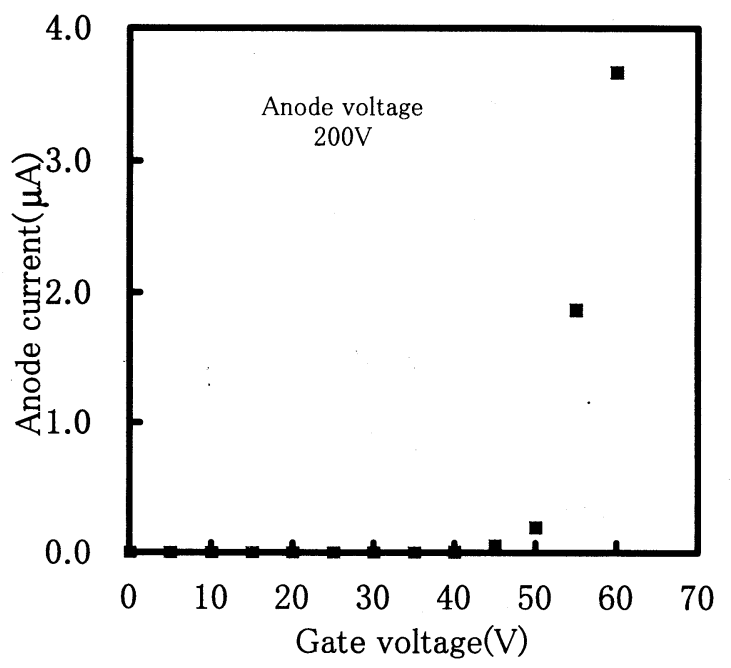

図 12 ゲート满造をもつ電界放出型微小電子源のみの放出電 流のゲート電正依例性

The dependence of the emission current on the gate vias of the fablicated gated emitter.

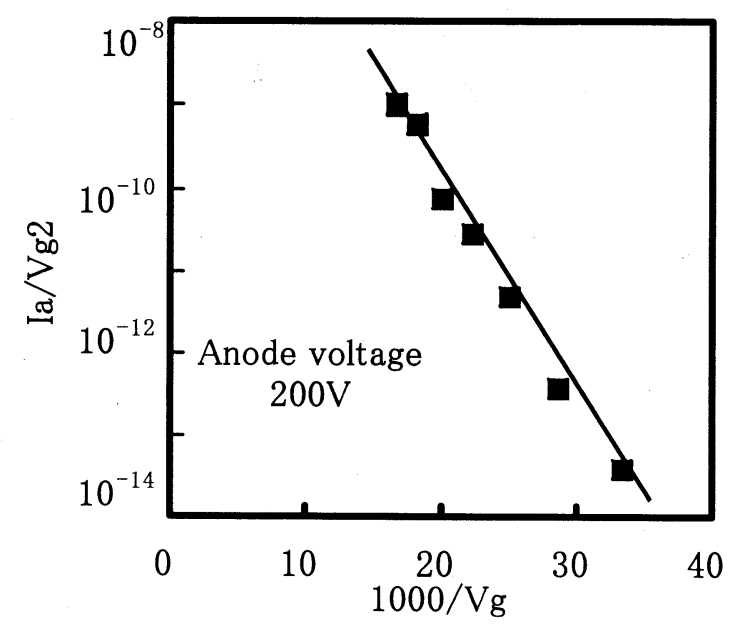

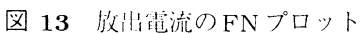

The FN plot of the emission current of the fablicated gated emitter.

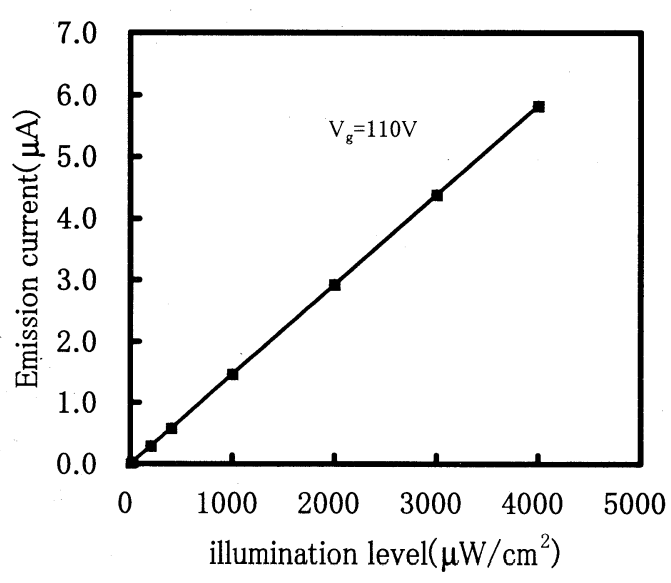

図 14 製作した 3 極管構造微小電子源の光電変換特性 The dependence of the emission currents on the incident light intencity.

の端子で測定してみると，100V 以上の逆バイアスを印加 してもブレークダウンせず，しかも良好な光電変換特性を 示すことがわかった。

そこで 3 極管構造をもつ微小電子源と, アモルファスシ リコンフォトダイオードを組合せた光センサを測定してみ た．そのときの光電変換特性を図 14 に示す．ゲートに印加 する電圧は $110 \mathrm{~V}$ とた。 またアノード電圧は200V一定に して測定している。図12の特性から，ゲート電庄を $110 \mathrm{~V}$ ほど印加することにより光を照射していないとき，フォト ダイオードには $(110 \mathrm{~V}-35 \mathrm{~V})=75 \mathrm{~V}$ の電圧が加わって

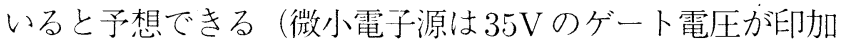
されるまで電子を放出していないことをこの節の最初に述 べた）。この電圧に扔いてはフォトダイオードは充分逆バ イアスされており飽和領域で動作している.

図14に示した光電変換特性から最大検出光量が $20 \mu \mathrm{W} / \mathrm{cm}^{2}$ から $4000 \mu \mathrm{W} / \mathrm{cm}^{2}$ と約 200 倍に増加できた ことがわかる。さらにこのときの暗電流も約 $10 \mathrm{nA}$ と低く 押さえることができた。また量子効率は約 $70 \%$ でった。

このときの負荷曲線を図15に示す。高い相互コンダ クタンスを持つフィールドエミッタを電子放出部としたこ とにより, 動作点はフォトダイオードの飽和領域に, 光量 を増やしても存在することがわかる。

さらに多量の光を照射してみたが，放出電流が $7 \mu \mathrm{A}$ を越えたところで微小電子源か破損してしまった。これは 多くの電流が微小電子源先端を流れたことで, そのジュー ル熱で破損したものと予想している。これは微小電子源を さらに多く集積することで解決でき, 最大検出光量の増加 が期待できる。

\section{5.むすび}

これまで報告してきた電界放出微小電子源を用いた光 検出素子の最大検出光量は約 $20 \mu \mathrm{W} / \mathrm{cm}^{2}$ と非常に低いも のであった，その原因は，電子放出部として用いている電 界放出微小電子源のコンダクタンスが小さいことにあっ 


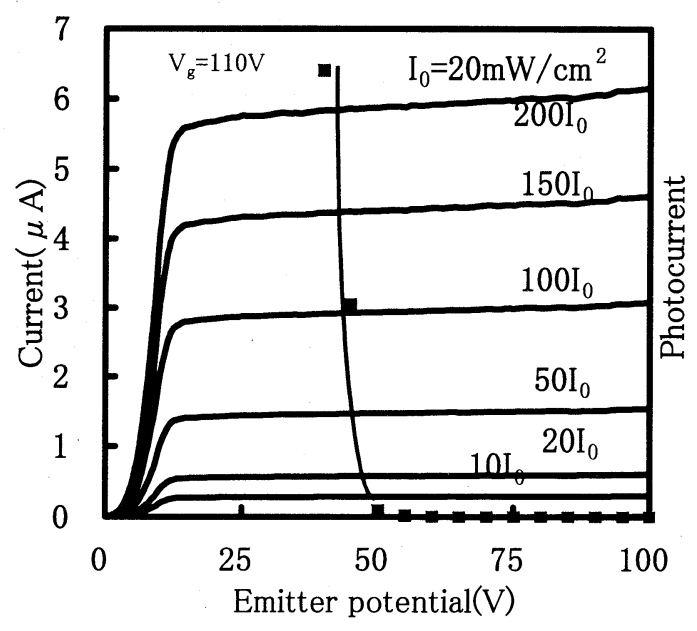

図 15 製作した 3 極管構造微小電子源の負荷曲線

The load line characteristic of the gated silicon emitter superimposed upon the a-Si:H pin photodiode film characteristic.

た. 微小電子源の小さなコンダクタンスを改善するために, ゲート構造をもうけた 3 極管電界放出微小電子源を試作し た。その結果, 高い相互コンダクタンスを持つ電子放出源 が試作できた，それを用いて，光検出素子を試作したとこ ろ，最大検出光量を約 200 倍とすることができた.

本研究は文部省科学研究費の援助により行われた。

\section{〔文献〕}

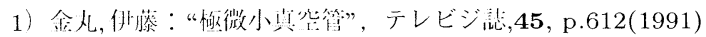

2) R.H.Fowler,L.H.Nordheim: "Electron Emission in Intense Electron Field",Proc.Roy.Soc., A119, p.173 (1928)

3) H.F.Gray, G.J.Czmpisi,R.F.Greene: "A Vacuum Field Effect Transistor using Silicon Field Emission Arrays",IEDM Tech.Dig.776(1986)

4) K.Sawada,K.Ji,T.Ando: "Characterization of p-type Silicon Field Emitters",Jpn. J .Appl. Phys., 33, p.L1345(1994)

5) K.Sawada,N.Matsumura,T.Ando: "Photosensitive Field Emitters Including a-Si:H p-i-n Photodetection Region",IEEE Trans. Electron Devices, 45, p.321 (1998)

6) R.N.Thomas,H.C.Nathanson: "Transamissive-Mode Silicon Field Emission array Photoemitter", Appl.Phys.Lett., 21, p.387 (1972)

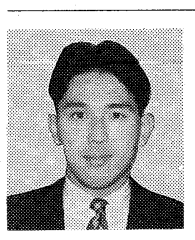

澤笛 架萂明 1991 年, 豊橋技術科学大学大学院博 士後期課程修了. 1991 年, 静周大学 電子工学研究所助 手. 1998 年, 豊橋技術科学大学满師. 主としてイメー ジセンサの高感度化に関する研究に従事. 工学博士. 正 会貣

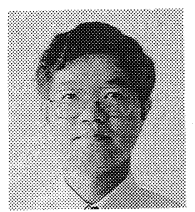

岩草誠 1979 年, 京都大学大学院博士後期 課程修了. 1979 年, 豊橋技術科学大学助手. 1991 年 〜1992 年, ベルギー王国 I ME C 客員研究員. 1997 年, 豊橋技術科学大学教授. S O I 棈造の形成とセンサ・集 積回路への応用についての研究に従事. 工学博士.

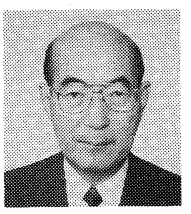

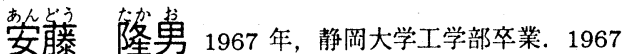
年, 日本電気 (株) 中央研究所入所. 1975 年, 静岡大 学電子工学研究所 助教授. 1981 年, 同大学教授. 1998 年, 同大学名誉教授. 撮像デバイスの固体化の基礎研究, 撮像デバイスの高機能化, アバランシェ增倍の撮像デバ イスへの応用などの研究に従事. 工学博士. 正会員. 